\title{
DISPONIBILITATEA FIZICĂ PROMPTĂ A MILITARILOR - CONCEPTE, PRINCIPII, COMPONENTE
}

\author{
PROMPT PHYSICAL AVAILABILITY OF THE MILITARY- \\ CONCEPTS, PRINCIPLES, COMPONENTS
}

\author{
Lt.col.instr.sup.dr. George-Florin BĂIŢAN*
}

\begin{abstract}
Rezistența (capacitatea de a susține activitatea), forța (capacitatea de a depăși rezistența) şi motricitatea (aplicarea funcțională a forței și a rezistenței pentru a reacționa operativ la stimuli, sub forma unei mișcări eficiente) sunt trăsături esențiale pentru randamentul fizic al militarilor și, pe o scară mai mare, pentru succesul lor în sistemul militar. Disponibilitatea fizică promptă este capacitatea de a satisface cerințele fizice ale oricărei situații de serviciu sau de luptă, în scopul de a îndeplini misiunea sau de a continua lupta până la obținerea victoriei. Privind în perspectivă, abordarea multidomeniu în cadrul operațiilor militare identifică nevoia ca militarii să fie în permanență pregătiţi din punct de vedere fizic, astfel încât aceștia să aibă disponibilitatea de a lupta în medii extrem de disputate și de dificile. Atât pregătirea tactică, cât și cea fizică vor rămâne componente cheie ale pregătirii pentru luptă, iar specialiștii în domeniul educației fizice militare trebuie să găsească soluții pentru a integra antrenamentul fizic în exercițiile tactice de antrenament în teren.
\end{abstract}

Endurance (the ability to sustain activity), strength (the ability to overcome endurance) and motor skills (the functional application of force and endurance to react operatively to stimuli in the form of effective movement) are essential features for the physical performance of the military and, on a larger scale, for their success in the military system. Prompt physical availability is the ability to meet the physical requirements of any service or combat situation, in order to fulfill the mission or continue the fight until victory is achieved. Looking ahead, the multi-field approach in military operations identified the need for the military to be constantly physically prepared so that they would be available to fight in extreme environments of dispute and difficulty. Both tactical and physical training will remain a key component of combat training, and military physical education specialists must find solutions to integrate physical training into tactical field training exercises.

Cuvinte-cheie: disponibilitate fizică promptă; concepte de instruire; pregătire fizică; antrenament; educație fizică militară.

Keywords: prompt physical availability; concepts of training; physical training; workout; military physical education.

Sistemul de educație fizică militară al armatei creează, pentru militari, oportunitatea zilnică de a-și perfecționa deprinderile și priceperile motrice necesare îndeplinirii misiunilor primite. Pregătirea fizică specifică este înrădăcinată în principiile antrenamentului sportiv și în cerinţele metodice generale ale acestuia, concepute pentru a avea un militar atletic, incluzând și activităţi de instruire care susțin direct sarcinile de luptă din cadrul întregului spectru de operații.

Obiectivul general al programului de formare a unei disponibilități fizice prompte este de a pregăti militari care să fie capabili, din punct de

\footnotetext{
*Academia Tehnică Militară „Ferdinand I” e-mail: baitan_george_florin@yahoo.com
}

vedere fizic, să-și îndeplinească sarcinile sau misiunile atât pe timpul antrenamentelor fizice, cât și în situațiile reale de luptă. Pentru a atinge acest obiectiv, activitățile fizice din cadrul programului de pregătire trebuie să vizeze următoarele aspecte: dezvoltarea unei forțe suficiente pentru a îndeplini sarcinile necesare și o rezistență adecvată pentru a susţine activitatea pe o perioadă lungă de timp, dezvoltarea tonusului muscular adecvat menţinerii unei posturi corecte și păstrarea unei greutăți corporale optime, perfecționarea anumitor deprinderi motrice de bază și utilitar-aplicative, care sunt esențiale pentru siguranța personalului și pentru o performanță eficientă în luptă.

Liderii militari din întreaga lume au recunoscut întotdeauna că eficacitatea militarilor depinde, în mare măsură, de starea lor fizică. Operaţiunile cu spectru complet (de luptă, de stabilitate şi sprijin 
sau operaţiile în timp de pace) pun un accent deosebit pe calitățile, deprinderile și priceperile motrice ale militarilor, componente de care depinde, în mare măsură, victoria finală sau chiar viața combatanţilor. Pentru a mărșălui pe distanțe lungi cu încărcătură (materialele și armamentul de luptă din dotare), parcurgând un traseu în teren variat și luptând eficient la sosirea în raionul de luptă, pentru a ridica și a transporta obiecte grele, pentru a conduce autovehicule militare cu viteză mare pe un teren accidentat, pentru a lua cu asalt pozițiile inamicului, executând sprinturi și deplasări târâş pe distanțe lungi, pentru a sări sau a escalada anumite obstacole, pentru a săpa trașee, a umple saci cu nisip sau a înlătura materialele reziduale și pentru a executa o deplasare rapidă mai multe ore fără pauză de odihnă, toate aceste acțiuni de război și multe altele necesită o disponibilitate fizică promptă din partea militarilor.

\section{Aspecte generale privind disponibilitatea fizică promptă la militari}

„Pregătirea fizică are ca finalitate satisfacerea cerinţelor fizice ale luptei armate din perspectiva militarilor pentru îndeplinirea sarcinilor de serviciu sau a misiunilor primite"1. Pregătirea fizică a militarilor a evoluat de-a lungul timpului pe baza abordărilor științifice interdisciplinare (militare și civile) din domeniul educației fizice. Aceste cercetări cu valoare istorică, precum și conceptele contemporane influențează programarea activităților fizice în armată. Programele de pregătire fizică trebuie să fie concepute pentru a îndeplini obiectivele de instruire ale militarului, ale subunitătii/unității și, prin extensie, ale armatei. Chiar dacă există similitudini cu programele de pregătire fizică din viața civilă, în sistemul militar specificul luptei și pericolele profesiei necesită o abordare diferită. Această abordare o putem numi disponibilitate fizică promptă (DFP) și se referă la calitatea sau la starea militarului de a fi permanent pregătit fizic, integrând concepte de instruire vechi, cum ar fi:

- antrenamentul de intensitate scăzută reprezintă un program de exerciții cardiovasculare, în care militarii efectuează o activitate aerobă la o intensitate redusă până la moderată, pe o perioadă lungă și continuă de timp. Odată ce intensitatea este atinsă, exercițiul poate continua atâta timp cât militarul își poate menține ritmul cardiac într-o zonă de antrenament prescrisă ${ }^{2}$ (un nivel la care inima este antrenată, dar nu supusă extenuării), iar energia lui continuă să fie disponibilă;

- antrenamentul în tempo - reprezintă o alergare confortabilă, pe o perioadă mai mare de timp (20 - 30 de minute), într-un ritm setat pentru o anumită distanță sau la un anumit nivel de efort perceput pentru un anumit interval de timp ${ }^{3}$. Este pur și simplu nivelul de efort la care organismul este capabil să elimine o cantitate de acid lactic (un produs secundar al arderii carbohidraților) egală cu cea produsă. Acest lucru înseamnă că senzațiile de picioare grele sau de brațe slăbite nu se vor mai instala. Dacă acest tip de antrenament va fi executat intermitent, atunci el va fi similar antrenamentului cu intervale;

- antrenamentul cu intervale (High Intensity Interval Training) - se bazează pe un principiu fundamental: repetarea alternativă a unei perioade scurte de antrenament de rezistență de intensitate ridicată, cu o perioadă de recuperare mai lungă. Acesta se poate efectua utilizând exercițiile tradiționale care stimulează efortul aerob (alergarea), sau utilizând, preponderent, intens muşchii din diverse regiuni ale corpului (exerciţiile pliometrice). Pe lângă faptul că antrenamentul cu intervale contribuie la îmbunătățirea stării de sănătate a militarilor, acesta creează o stare de bine superioară în rândul celor care-l execută, aceștia dorindu-și să practice un astfel de tip de antrenament și în viitor;

- antrenamentul în circuit-reprezintă o metodă de antrenament populară și foarte eficientă în timp, un mod excelent de a îmbunătăți capacitatea cardiovascularășirezistențaforțeimusculare.Acesta va ridica ritmul cardiac și îl va menține ridicat pe tot parcursul circuitului, datorită perioadelor scurte de recuperare, mușchilor mari lucrați concomitent și datorită unei combinații de exerciții fizice care solicită întregul corp. Antrenamentul în circuit este o alegere excelentă pentru pregătirea fizică a militarilor, mai ales dacă timpul de instruire este scurt, dacă aceștia se plictisesc repede sau dacă nu le place să se antreneze singuri, lucruri care-1 fac ideal pentru antrenamentul de grup într-un spațiu limitat;

- antrenamentul încrucișat (Cross Training) - reprezintă o metodă de condiționare fizică, ce implică mai multe tipuri diferite de exerciții fizice, care vor fi rotite în diferite moduri pe parcursul 
programului dintr-o săptămână sau în cadrul unei ședințe de antrenament. Acesta nu trebuie să fie foarte intens, deoarece, în esență, este vorba despre asocierea antrenamentelor care se vor susține reciproc și care vor solicita mai multe grupe musculare, îmbunătățind agilitatea și facilitând participarea la o varietate de sporturi recreative. Antrenamentul încrucișat limitează stresul care apare pe anumiți mușchi, deoarece activitățile diferite folosesc muşchii în moduri uşor diferite. În plus, Cross Trainingul reduce plictiseala și îi menține motivați pe militari;

- antrenamentul „trage-împinge” (push-pull) - se referă, în general, la ședințele de antrenamente de forță, centrate în jurul grupurilor musculare care efectuează acțiuni similare, alternând între mușchii agoniști și cei antagoniști. Astfel: antrenamentul „trage” va antrena mușchii spatelui superior, bicepsul și antebrațele, în timp ce antrenamentul „împinge” va antrena mușchii pieptului, tricepsul și umerii. În această sesiune de antrenament, trebuie inclusă și o ședință pentru antrenarea membrelor inferioare și a abdomenului, creând astfel unul dintre cele mai eficiente programe pentru creșterea masei musculare;

- antrenamentul ,,superior-inferior” (upper-lower) - se referă la ședințele de antrenament de forță în care se lucrează alternativ, în ședințe distincte, grupele musculare majore din partea superioară a corpului, apoi cele din partea inferioară. Acest lucru va permite efectuarea antrenamentelor în zile succesive, deoarece nu există o suprapunere între mușchii solicitați în două antrenamente consecutive. Acest tip de antrenament oferă o oportunitate pentru diversitate, deoarece militarii nu sunt limitați doar la anumite grupe musculare pentru fiecare antrenament, ci pot alege dintr-o gamă largă de exerciții. Astfel, ei pot efectua exerciții complet diferite la fiecare antrenament, varietate care îi va ajuta să rămână implicați și să evite plictiseala;

- antrenamentul ,, agonist-antagonist” (superset) - este o formă de antrenament de forță în care se lucrează două grupe musculare opuse, trecând rapid de la un exercițiu la alt exercițiu, fără a lua o pauză pentru odihnă între serii (cel mult un repaus scurt pentru hidratare). Superseturile pot fi utilizate ca o modalitate de a face mai multe exerciții într-o perioadă limitată de timp, deoarece, nefăcând pauză, mușchii care au fost solicitați într-o serie de exercitiii se vor recupera pe timpul următoarei serii în care ei nu sunt implicați. Superseturile pun accent pe rezistență (precum și pe îndemânare), deoarece lipsa unei recuperări fizice între serii poate fi extrem de provocatoare.

\section{Principiile disponibilității fizice prompte a militarilor}

Principiile DFP ale militarilor sunt precizia, progresia și integrarea. Aceste principii oferă posibilitatea ca militarii să execute cu precizie toate exercițiile fizice, deprinderile și priceperile motrice cuprinse în structura unui program de pregătire fizică. Ei vor progresa din punct de vedere fizic și își vor forma mult mai repede abilitățile pentru luptă, specifice fiecărei arme/servicii și specialități militare în parte. Din punct de vedere psihologic, principiile DFP vor dezvolta capacitatea de a lucra în echipă, disciplina, autocontrolul, vor sprijini îndeplinirea automată a îndatoririlor de serviciu în situații dificile și vor iniţia un răspuns instinctiv la ordinele date de către comandanți.

Precizia se referă la faptul că o mișcare precisă depinde de capacitățile structurale și funcționale ale organismului, de o mobilitate și de o suplețe adecvată, de toleranța de a suporta o greutate suplimentară, de compoziția corpului și de conexiunea creierului cu mușchii. Toate aceste tipare motorii vor permite militarilor să învețe care este standardul și să perceapă diferența dintre tehnicile corecte și cele incorecte. Calitatea mișcării este la fel de importantă precum greutatea ridicată, numărul repetărilor efectuate sau viteza de execuție, iar deprinderile motrice ale mișcărilor se vor dezvolta prin execuții repetate și prin practicarea deliberată a activităţilor fizice.

Repetiția, folosind imaginile mentale, poate ajuta la rafinarea tiparelor precise de mișcare, fără a depune un efort fizic deosebit. Principiul preciziei asigură dezvoltarea percepției și conștientizarea poziţiei corpului în spațiu (,,posibilitatea de a simți, fără participare vizuală, prin intermediul sensibilităţii profunde, mișcările imprimate pasiv diverselor segmente ale corpului"4), pentru a îmbunătăți parametrii antrenamentului, rezultatele evaluărilor și performanțele pe câmpul de luptă.

Progresia se referă la dozarea adecvată a efortului fizic, ținând cont de elementele fundamentale ale acestuia (volum, frecvență, intensitate și complexitate) și de tipul de exerciții fizice necesare 
solicitării progresive a organismului, fără a provoca procesul numit supraantrenament. Scopul acesteia îl reprezintă dezvoltarea capacității fizice pentru a sprijini stăpânirea sarcinilor profesionale și specifice luptei. Analiza sarcinii include cerințele fiziologice ale sarcinii și potențialele probleme de performanță sau pericole de accidentare cu care militarii s-ar putea confrunta ${ }^{5}$. Progresia corectă a parametrilor de bază în dezvoltarea efortului și varietatea de exerciţii utilizate vor evolua de la faza iniţială, până la faza de perfecționare. Antrenamentele executate în faza iniţială de pregătire fizică vor crea o condiție fizică de bază, pe care militarii o vor folosi pentru a progresa în siguranță la niveluri mai ridicate, de capacitate fizică operațională. De aceea este important să ne amintim faptul că abilitatea de mișcare va necesita o revizuire consistentă a elementelor de bază, înainte și după fiecare progres, la un nivel superior.

Principiul integrării se concentrează pe activitățile și exercițiile fizice efectuate de militari, pentru a le permite acestora să lupte și să obțină victoria. Armata pregătește militarii și unitățile sale pentru a lupta şi pentru a câștiga, folosind o listă specifică cu abilitățile pentru luptă, necesare tuturor militarilor (indiferent de grad, de armă sau de specialitate militară). Acestea reprezintă o colecție de deprinderi motrice individuale, legate de capacitatea unui militar de a executa trageri $\mathrm{cu}$ toate categoriile de armament, de a se deplasa pe jos în teren variat, de a supraviețui în condiții extreme și în locaţii periculoase, de a comunica cu ceilalți militari parteneri, de a acorda primul ajutor, în caz de necesitate etc. Deprinderile motrice necesare într-o luptă sunt acele abilități de grup concepute pentru a învăța o unitate să reacționeze și să supraviețuiască în diverse situaţii tactice de luptă. Fiind sprijiniți în mod regulat de specialiștii în educație fizică militară (prin instruire), toți comandanții trebuie să se asigure (prin testare) că militarii din subordine pot executa toate aceste abilităţi.

Militarii care vor respecta aceste principii vor deveni mai pregătiți din punct de vedere fizic, aceasta nefiind o rețetă de fitness recreativ. Această pregătire fizică are ca scop dezvoltarea capacităţii fizice pentru a susține toate specialitățile militare și sarcinile specifice luptei. Odată ce militarii ating un nivel ridicat de pregătire fizică în faza iniţială, ei trebuie să continue să-și construiască această pregătire de bază, concomitent cu dezvoltarea lor fizică, în concordanţă cu cerinţele esenţiale ale misiunii care urmează a fi îndeplinite.

Această doctrină (formată din cele trei principii ale DFP) integrează antrenamentul fizic cu antrenamentul nonfizic (domenii care se integrează cu planul de pregătire fizică). Obiectivele instruirii trebuie să țină seama de capacitatea militarilor de a efectua activităţi solicitante fizic și psihic (în medii cu variaţii extreme de căldură, frig și umiditate), concomitent cu transportarea unui echipament de protecție individuală împovărat. Programul de recuperare dintre ședințele de antrenament trebuie instruit, măsurat și fixat, iar specialiștii în educație fizică militară trebuie să gestioneze toate obstacolele care apar în calea atingerii obiectivelor (supraantrenamentul sau stagnarea nivelului de performanță). În consecință, ședințele de antrenament ale militarilor trebuie să se succeadă la intervale regulate de timp, determinate de vârful fazei de adaptare a organismului acestora la solicitările ședinței precedente ${ }^{6}$.

\section{Componentele disponibilităţii fizice prompte a militarilor}

Ansamblul de exerciţii de educație fizică militară utilizate pentru a obține o formă fizică bună, în mod obișnuit este împărțit și măsurat în părți. Adesea, acestea au fost etichetate drept componente, care au evoluat odată cu progresele în știința și tehnologia exercițiilor fizice. Militarii trebuie să se antreneze în toate componentele fitnessului, pentru a putea răspunde unei game infinite de provocări operaționale și cerințtelor fiziologice.

Cerinţele structurale sunt caracteristici fizice și cognitive care stau la baza unei capacităţi sporite de muncă. Ele permit creșterea capacității de muncă prin participarea sistematică la ședințele de antrenament fizic, acestea creând: o compoziție corporală sănătoasă (raportul dintre grăsime și masa musculară), un raport optim între greutate și înălțime, o densitatea osoasă mare (oase puternice), o flexibilitate statică bună (care va contribui la îmbunătăţirea echilibrului și a coordonării), un timp de reacție rapid și o percepție îmbunătățită asupra poziției și mișcării corpului. Pe scurt, militarii au nevoie de aceste cerințe structurale pentru a începe instruirea și pentru a finaliza cât mai multe sarcini de serviciu. „Succesul forțelor angajate în conflicte depinde în mare măsură de valoarea 
prestației motrice și de nivelul calităților psihice ale personalului care deservește armamentul, echipamentele și tehnica de luptă"’ .

Sistemul de pregătire fizică trebuie conceput astfel încât militarii să progreseze prin antrenamente (regulate și graduale în intensitate și complexitate), care să le dezvolte la maximum duritatea mentală $\breve{8}^{8}$ și deprinderile de luptător. Unii pot atinge niveluri individuale de performanță, superioare, inspirându-i astfel și pe ceilalți să își dorească același lucru, dar capacitatea funcțională fiziologică maximă a întregii subunități (ușurința de a îndeplini sarcinile fizice din viaţa de zi cu zi) este aspectul care trebuie să-1 intereseze, în primul rând, pe un comandant, nu performanța deosebită a unui singur militar.

În situația în care un militar trebuie să ridice o greutate de $50 \mathrm{~kg}$, iar forța lui maximală este de $150 \mathrm{~kg}$ (se referă la cea mai mare încărcătură pe care o poate manevra la un moment dat ${ }^{9}$ ), acest efort este unul relativ ușor. Nivelul lui ridicat de putere musculară îi va permite să folosească relativ mai puțin efort pentru a finaliza sarcina, conservându-și astfel energia pentru următorul efort. Aceeași greutate va fi mult mai dificil de ridicat, și efortul depus mult mai intens pentru cineva a cărui forță maximală este de 75 de $\mathrm{kg}$. Cu cât greutatea materialului care trebuie manevrat manual se va apropia de forța maximală a unui militar, cu atât riscul de rănire va fi mult mai mare. Conducătorii activităților trebuie să difere și să individualizeze programul de pregătire fizică a militarilor pentru a îmbunătăți volumul de muncă absolut și pentru a evita apariţia accidentărilor. Cei care vor înțelege și vor aplica conceptul de forță maximală, cuantificând ședințele de pregătire fizică, plecând de la valoarea acesteia, vor individualiza strict antrenamentele, în concordanță cu cerințele misiunii care trebuie executată.

Disponibilitatea fizică promptă a militarilor trebuie să includă, cu precădere, următoarele componente: forța musculară, hipertrofia musculară funcțională, rezistența musculară, rezistența aerobă, rezistența anaerobă și puterea musculară.

Forța musculară reprezintă nivelul forței pe care îl poate genera un mușchi sau un grup de muşchi prin tensiunea realizată de aceștia în timpul contracțiilor musculare. Exemple de exerciții și de situații în care este folosită, cu precădere, forța musculară: atârnat la bara fixă cu brațele flexate și cu bărbia deasupra barei (timp de minimum 20 de secunde), împins din culcat cu haltera, genuflexiuni cu haltera la ceafă, îndreptări cu haltera sau extragerea unui militar rănit printr-o trapă a unei turele. Totuși, cea mai utilă modalitate pentru măsurarea forței musculare este testul 1RM (o repetare maximă), care stabilește care este cea mai mare greutate pe care o poate manevra un militar.

Nivelurile ridicate ale forței atinse în timpul misiunilor pot fi, cu siguranță, realizate și fără a manevra greutăți maximale, punând în pericol integritatea corporală a militarilor. De fapt, specialiștii trebuie sățină cont de rezultatele obținute de militari la testul 1RM și să stabilească sarcini subordonaţilor, astfel încât aceștia să folosească aproximativ $80-90 \%$ din valorile acestora. În acest sens, se poate utiliza și formula, pentru calcularea valorii unei repetări maxime:

\section{$I R M=(0,033 \times$ numărul repetărilor efectuate $x$ valoarea greutății manevrate) + valoarea greutăţii manevrate}

Prin urmare, testarea periodică pentru stabilirea valorii maxime a forței musculare este importantă pentru a monitoriza progresul și pentru a modifica programul de pregătire fizică, în funcție de nevoile individuale. „Nivelul de dezvoltare al acestei calități, alături de rezistență în special, condiționează direct capacitatea de efort a acestora, factor esențial în îndeplinirea cu succes a misiunilor încredințate și, în anumite momente, în însăși supraviețuirea militarului combatant sau a camarazilor acestuia"10.

Hipertrofia musculară funcțională (,,calea muşchilor utilizabili”) reprezintă un proces complex de creștere a dimensiunii mușchilor, care poate fi realizat prin antrenamente specifice (hipertrofice), în care sunt combinate ședinţele de dezvoltare a forței musculare și a rezistenței musculare. Termenul de funcțional se referă la faptul că militarii trebuie să se antreneze, astfel încât să poată executa activităţi fizice la un nivel cât mai înalt atât în mediul militar, cât și în viața de zi cu zi. Pentru declanşarea hipertrofiei musculare, militarii trebuie să folosească încărcături moderate și grele (între 65 şi $85 \%$ din 1RM), un număr mai mare de repetări/antrenamente, pauze scurte între seriile de exerciții și o varietate de viteze de execuție a mișcărilor.

Rezistența musculară reprezintă capacitatea unui mușchi sau a unei grupe musculare de a susține 
un efort (de a efectua în mod repetat contracții împotriva unei forțe) pe o perioadă lungă de timp. Ea se referă la numărul de repetări, din cadrul unui singur exercițiu, pe care un militar poate să le execute fără a fi nevoit să se oprească pentru odihnă. Cu cât este mai mare rezistența musculară, cu atât este mai mare numărul de repetări pe care militarul le poate realiza. Drept exemplu, avem: ridicarea și așezarea unor materiale într-un camion, încărcarea unui tun cu proiectile sau efectuarea de exerciții calistenice la bara fixă. În combinație cu rezistența aerobă și cu cea anaerobă, rezistența musculară este necesară pentru a suporta transportarea sarcinilor din ce în ce mai grele în teren variat, pe distanţe lungi și cu viteză mai mare. Proba de flotări ${ }^{11}$, desfășurată contratimp, din cadrul evaluărilor semestriale la educație fizică militară, reprezintă un test folosit adesea pentru a măsura rezistența musculară a trenului superior.

Rezistența aerobă este capacitatea de a pune în acțiune grupe musculare mari pentru o perioadă mai lungă de timp (peste două minute), aceasta depinzând de starea funcțională a sistemului cardiovascular (care furnizează mușchilor oxigen și nutrienți). Deși antrenamentul aerob este de intensitate redusă, un volum mare al acestuia, fără a avea o dozare adecvată (serii, repetări, greutate, frecvenţă) poate provoca supraantrenament. Dacă se menține același ritm, încărcăturile mari transportate în timpul activităţilor aerobice au tendinţa să schimbe componenta de fitness, de la cea aerobă, la cea anaerobă. Militarii, indiferent de nivelul lor de pregătire fizică, vor începe să încetinească ritmul, atunci când transportă sarcini grele, lucru care va scădea semnificativ efectul de antrenament aerob și va crește riscul de apariție a accidentărilor. Exemple de eforturi aerobe pe care le desfășoară militarii: alergarea în teren variat şi deplasarea rapidă pe distanțe lungi, marșurile, patrulele etc.

Rezistența anaerobă se referă la capacitatea de a susține o activitate fizică intensă, de scurtă durată (aproximativ un minut).La acest tip de efort, mușchii cu contracție rapidă sunt cei mai mari contribuabili. Combustibilul pentru acest tip de exerciţii fizice intense este derivat, în principal, din surse de energie care sunt deja prezente în corp (cum ar fi desfacerea glicogenului în monozaharide, precum glucoza). Rezistența anaerobă este finită și, prin urmare, este asociată cu oboseala completă. Nivelul ridicat al rezistenței anaerobe este esențial pentru transportul încărcăturilor grele. Exemple de eforturi anaerobe pe care le desfăşoară militarii: sprinturile, săriturile peste diverse obstacole, ridicarea greutăţilor, lupta corp la corp cu sau fără armamentul individual din dotare, deplasarea rapidă, transportând o greutate mare etc. „Solicitările fizice și psihice din ce în ce mai mari, specifice câmpului de luptă modern, fac din rezistență un factor deosebit de important prin care militarul poate învinge apariţia timpurie a oboselii, atât în domeniul intelectual, senzorial, emoțional, cât și în cel fizic"12.

Puterea musculară reprezintă abilitatea de a muta o greutate (inclusiv greutatea corpului) într-o viteză cât mai mare (aplicarea forței în timp). Puterea musculară este rezultatul atât al forței, cât și al cerințelor de viteză pe care le impune desfășurarea unei activități, care poate fi descrisă ca fiind rata de lucru pe unitate de timp. Durata antrenamentelor pentru dezvoltarea puterii musculare se măsoară în secunde (sau fracțiuni de secundă) și se caracterizează printr-un efort maxim. Antrenamentele specifice vor include exerciţii de forță explozive (4 - 6 repetări/serie), executate cu îngreunare sau cu opunere de rezistență și urmate de intervale lungi de odihnă. Dacă sunt practicate constant în antrenament, acestea pot îmbunătăti performanța fizică necesară ducerii acțiunilor de luptă și pot reduce riscul de accidentare a militarilor în timpul activităților care implică mișcări explozive de forță, viteză și putere, cu accelerare rapidă. Exemple de activități în care este folosită puterea musculară: aruncarea grenadelor de mână la distanță, sărituri în lungime peste obstacole, evacuarea răniților, împingerea unui vehicul blocat în noroi etc.

\section{Concluzii}

Lucrurile asupra cărora se concentrează militarii tind să aibă efecte pozitive asupra traiectoriei carierei lor. Atunci când militarii vor învăța să acorde mai multă atenție sănătății și stării lor fizice, și starea organismului va fi una mai bună, iar nivelul lor de pregătire fizică va fi mai ridicat. Aceștia sunt capabili să creeze noi căi neurale și, implicit, noi obiceiuri care le vor schimba modalitățile de reacție, de a decide și de a se comporta.

În structurile militare în care alegerea unui stil de viață sănătos este apreciată și încurajată, membrii acesteia au o mai mare capacitate de autocontrol, necesară pentru a face alegeri corecte. Când militarii 
învață să se concentreze asupra evenimentelor pozitive, este mai probabil ca ei să depășească momentele negative, pe care toți avem tendința să le vedem mai întâi. Pentru a pregăti din punct de vedere fizic cu succes o subunitate, specialistul în educaţie fizică militară trebuie să aibă abilitatea de a acorda de trei ori mai mult feedback pozitiv/ apreciativ decât feedback negativ/critic.

Militarii au propria lor perspectivă asupra educaţiei fizice, formată din istoria personală de viață, din experiențele afective trăite și din educația primită. Schimbarea perspectivelor necesită o muncă grea deliberată atât din partea lor, cât și din partea comandanților și a specialiștilor în domeniul educaţiei fizice militare, pentru a orienta instruirea, predarea și îndrumarea pregătirii fizice a militarilor. Concentrarea pe conceptele, principiile și componentele DFP poate avea un impact pozitiv asupra viziunii militarului despre organizaţia militară.

Consider că obsesia modernă de efectuare a ședințelor de antrenament cu o intensitate constant ridicată şi de dezvoltare rapidă a unei mase musculare excesive, pentru a avea un corp frumos proporționat, este în detrimentul sănătății și duratei normale a vieții. Există multe lecții învățate din experiența generațiilor anterioare, de care trebuie să ținem cont, în special adevăratul sens al educației fizice militare. Desfășurarea sistematică, timp de mai mulţi ani, a unor activități fizice eficiente, evitând riscul apariției unor leziuni, cauzate de suprasolicitarea fizică, cu scopul de a perfecționa abilitățile motrice necesare luptătorilor (oricât de complexe ar fi ele), ar trebui să fie scopul final în crearea unei disponibilități fizice la militari.

\section{NOTE:}

1 G.C. Ciapa, Pregătirea fizică a militarilor din Armata României în conflictele moderne, Editura Universităţii Naționale de Apărare ,, Carol I”, București, 2018, p. 56.

$2 \mathrm{https}$ ://www.romedic.ro/ritmul-cardiac-in-timpulantrenamentelor-fizice-0C34797, accesat la 05.05.2021.

$3 \mathrm{https}$ :/www.andreirosu.org/2014/04/elucidarea-mist erului-alergarii-in-tempo, accesat la 06.05.2021.

$4 \mathrm{https}$ //www.revistagalenus.ro/dictionar-medical/kin estezie, accesat la 20.04.2021.

5 https://muhaz.org/universitatea-din-bacu.html?page $=7$, accesat la 21.04.2021.

$6 \mathrm{https}$ //www.escalada.verticon.ro/antrenament/princi pii.htm, accesat la 24.04.2021.

7 A.D. Pelmuș, Dezvoltarea capacității motrice a personalului militar, Editura Centrul Tehnic-Editorial al Armatei, București, 2021, p. 118.

8 Se referă la orice set de atribute pozitive care ajută un militar să facă față situațiilor dificile.
9, ,1RM” (o repetare maximală).

10 M.C. Istrate, „Forța - calitate motrică cu impact determinant în activitatea militară", Buletinul Universităţii Naţionale de Apărare „, Carol I” nr. 3/2020, București, p. 210.

11 Militarii de sex feminin vor executa flotările cu sprijin pe genunchi (semi-flotările).

12 A.D. Pelmuş, Dezvoltarea capacității motrice a personalului militar, Editura Centrul tehnic-editorial al armatei, București, 2021, p. 69.

\section{BIBLIOGRAFIE}

*** FM 7-22, Army Physical Readiness Training, Headquarters, Department Of the Army, Red Bike Publishing, 2013.

*** FM 7-22, Holistic health and fitness, Headquarters, Department Of the Army, Washington DC, 2020.

*** Regulamentul educaţiei fizice militare, Editura Centrul tehnic-editorial al armatei, Bucureşti, 2013.

Andrei I., „Importanța pregătirii fizice în procesul de instruire militară", Editura Universității Naționale de Apărare „Carol I”, București, 2015.

Băițan G.F., Pregătirea fizică a militarilor din Armata României în contextul integrării în NATO, Editura Universităţii Naţionale de Apărare „Carol I”, Bucureşti, 2019.

Ciapa G.C., Pregătirea fizică a militarilor din Armata României în conflictele moderne, Editura Universităţii Naţionale de Apărare „Carol I”, București, 2018.

Istrate M.C., ,Forța - calitate motrică cu impact determinant în activitatea militară", Buletinul Universităţii Naţionale de Apărare "Carol I" nr. 3/2020, București.

Pelmuș A.D., Dezvoltarea capacității motrice a personalului militar, Editura Centrul TehnicEditorial al Armatei, București, 2021.

Pop N.H., Zamora E., Creșterea volumului și forței musculare - elemente teoretice, practice și metodice, Editura Risoprint, Cluj-Napoca, 2007.

https://www.romedic.ro/ritmul-cardiac-intimpul-antrenamentelor-fizice-0C34797

https://www.andreirosu.org/2014/04/ elucidarea-misterului-alergarii-in-tempo

https://www.revistagalenus.ro/dictionar-medic al/kinestezie

https://muhaz.org/universitatea-din-bacu. html?page $=7$

https://www.escalada.verticon.ro/antrena ment /principii.htm 